\title{
Corrigendum: Enhancing Heat Tolerance of the Little Dogwood Cornus canadensis L. f. with Introduction of a Superoxide Reductase Gene from the Hyperthermophilic Archaeon Pyrococcus furiosus
}

\author{
Xing-Min Geng ${ }^{1,2 \dagger}$, Xiang Liu' ${ }^{1 \dagger}$, Mikyoung $\mathrm{Ji}^{1}$, William A. Hoffmann ${ }^{1}$, Amy M. Grunden ${ }^{1 *}$ \\ and Qiu-Yun J. Xiang ${ }^{1 *}$ \\ ${ }^{1}$ Department of Plant and Microbial Biology, North Carolina State University, Raleigh, NC, USA, ${ }^{2}$ College of Landscape \\ Architecture, Nanjing Forestry University, Nanjing, China
}

\section{OPEN ACCESS}

Edited and reviewed by: David John Burritt, University of Otago, New Zealand

*Correspondence:

Qiu-Yun J. Xiang

jenny_xiang@ncsu.edu; Amy M. Grunden

amy_grunden@ncsu.edu

${ }^{\dagger}$ Co-first authors.

Specialty section:

This article was submitted to

Plant Biotechnology,

a section of the journal

Frontiers in Plant Science

Received: 05 February 2016 Accepted: 10 February 2016 Published: 24 February 2016

Citation: Geng X-M, Liu X, Ji M, Hoffmann WA, Grunden AM and Xiang Q-YJ (2016) Corrigendum: Enhancing Heat Tolerance of the Little Dogwood Cornus canadensis L. f. with Introduction of a Superoxide Reductase Gene from the Hyperthermophilic Archaeon

Pyrococcus furiosus.

Front. Plant Sci. 7:226.

doi: 10.3389/fpls.2016.00226
Keywords: antioxidant enzyme, Cornus canadensis, genetic transformation, heat tolerance, Pyrococcus furiosus, reactive oxygen species (ROS), superoxide reductase (SOR)

\section{A Corrigendum on}

Enhancing Heat Tolerance of the Little Dogwood Cornus canadensis L. f. with Introduction of a Superoxide Reductase Gene from the Hyperthermophilic Archaeon Pyrococcus furiosus by Geng, X.-M., Liu, X., Ji, M., Hoffmann, W. A., Grunden, A., and Xiang, Q.-Y. J. (2016). Front. Plant Sci. 7:26. doi: 10.3389/fpls.2016.00026

The Author Contributions were erroneously reported in the original article. The statement that reads: "Q-YX generated and propagated the transgenic plants, conducted the gene sequencing and expression analyses, finalized figures, and manuscript revision. X-MG and Q-YX contributed equally to the projects" should have been provided as "XL generated and propagated the transgenic plants, conducted the gene sequencing and expression analyses, figure finalization, and manuscript revision. XG and XL contributed equally to the projects." XL is a research specialist in Q-YX's lab.

This correction does not affect the scientific validity of the results.

\section{AUTHOR CONTRIBUTIONS}

All authors listed, have made substantial, direct and intellectual contribution to the work, and approved it for publication.

Conflict of Interest Statement: The authors declare that the research was conducted in the absence of any commercial or financial relationships that could be construed as a potential conflict of interest.

Copyright (c) 2016 Geng, Liu, Ji, Hoffmann, Grunden and Xiang. This is an open-access article distributed under the terms of the Creative Commons Attribution License (CC BY). The use, distribution or reproduction in other forums is permitted, provided the original author $(s)$ or licensor are credited and that the original publication in this journal is cited, in accordance with accepted academic practice. No use, distribution or reproduction is permitted which does not comply with these terms. 